\title{
Ethnocentrism as a Short-Term Force in the 2008 American Presidential Election
}

\author{
Cindy D. Kam Vanderbilt University \\ Donald R. Kinder University of Michigan
}

\begin{abstract}
Faced with a choice between John McCain and Barack Obama, voters in 2008 were swayed by the familiar play of factorsparty identification, policy preferences, and economic conditions-but also, we find, by ethnocentrism, a deep-seated psychological predisposition that partitions the world into ingroups and outgroups-into "us" and "them." The effect of ethnocentrism was significant and substantial, and it appeared over and above the effects due to partisanship, economic conditions, policy stances, political engagement, and several varieties of conservatism. Two features of Obama were primarily responsible for triggering ethnocentrism in 2008: his race and his imagined Muslim faith. As such, we demonstrate that ethnocentrism was much more important in 2008 than in the four presidential elections immediately preceding 2008, and we show that it was much more important in the actual contest between Senator McCain and Senator Obama than in a hypothetical contest between Senator McCain and Senator Clinton.
\end{abstract}

$\tau$ n many ways, voters in the 2008 American presidential election faced a familiar scene. As always, the two major parties nominated men. Prior to their nominations, both candidates had held responsible leadership positions. Both recruited expert and experienced staffs. Both spent an astonishing amount of money in pursuit of votes. And, for the most part, both focused their campaigns on important issues: peace, prosperity, health care, and more. All of this follows a familiar script. At the same time, the 2008 election also presented Americans with something new: a candidate who broke utterly with tradition; a candidate who we think provoked many Americans to question whether he was really "one of us."

We are speaking here, of course, about Barack Obama. Obama was different. First of all, he was blackor at least he was taken to be black. His father was African, born and raised in Kenya. His mother grew up on a farm in Iowa - what could be more normal than that! - but became an anthropologist and (worse yet) a cosmopolitan. Obama spent his early years in exotic settings: Hawaii and then Indonesia. Many Americans wondered (and even at this writing still wonder) whether he is a citizen of the United States. Some believed him to be a Muslim. His very name—-Barack Hussein Obama—was disturbing.
In some ways real, in some ways imagined, Obama was perceived by many Americans to be different. The purpose of our article is to demonstrate that this perception of difference operated as a powerful short-term force in the 2008 election. More precisely, we intend to show that opposition to Obama in 2008 was driven, in part, by ethnocentrism.

By ethnocentrism we refer to a deep-seated psychological predisposition that partitions the world into ingroups and outgroups—into "us" and "them." Symbols, values, and practices become objects of attachment and pride when they belong to the ingroup, and they become objects of condescension, contempt, and in extreme cases, hatred when they are seen to belong to outgroups. Defined this way, ethnocentrism is an ancient phenomenon, but it is a modern word, invented at the opening of the twentieth century by William Graham Sumner. In Folkways ([1906] 2002), Sumner set out a bold conjecture: that members of all human groups believe that their way of doing things (their folkways) are superior to the way things are done elsewhere. "Ethnocentrism," as Sumner called it, is the "technical name for this view of things in which one's own group is the center of everything" (1906, 12).

Cindy D. Kam is Associate Professor of Political Science, Vanderbilt University, PMB 0505, Nashville, TN 37203 (cindy.d.kam@vanderbilt .edu). Donald R. Kinder is the Philip E. Converse Collegiate Professor of Political Science, University of Michigan, 5753 Haven Hall, Ann Arbor, MI 48109-1045 (drkinder@umich.edu). Electronic files for replicating all results are available at https://my.vanderbilt.edu/cindykam upon publication.

American Journal of Political Science, Vol. 56, No. 2, April 2012, Pp. 326-340

(C) 2012, Midwest Political Science Association

DOI: $10.1111 / j .1540-5907.2011 .00564 . x$ 
Sumner was convinced that ethnocentrism was a universal feature of human society, and he was not far from wrong. Everywhere we look, outsiders are greeted with suspicion and animosity. Around the world, ethnocentrism prevails (Brewer and Campbell 1976; Kinder and Kam 2009).

But if ethnocentrism is ubiquitous-if, as John Higham declares, "no age or society seems wholly free from unfavorable opinions on outsiders" (1955, 3)ethnocentrism as a concept in political analysis has been, until recently, all but invisible. Ethnocentrism is hard to find in contemporary social science theorizing, and it is especially hard to find in empirical studies of American elections and public opinion (Kinder and Kam 2009; LeVine 2001).

We think this a mistake and have done our best to correct it (Kinder and Kam 2009). In previous work we have shown that ethnocentrism is pervasive in modern American society; that Americans differ-reliably and stably-in the degree to which they approach the social world from an ethnocentric point of view; and that this one difference has far-reaching consequences for the positions Americans take on important matters of policy. Providing for the national defense, dealing harshly with enemies abroad, withholding assistance to foreign lands in need, stemming the tide of immigration, pushing back against gay rights, cutting welfare, and putting an end to affirmative action: in all these cases, ethnocentrism plays an independent, significant, and sizable role (Kinder and Kam 2009). We expect the same will be true in the 2008 election: that ethnocentrism will play an independent, significant, and sizable role in motivating opposition to Obama.

For empirical analysis, we rely primarily on two sources of evidence. First and foremost is the 2008 American National Election Study (ANES), based on face-toface interviews with a representative sample of American adult citizens. We also draw on the Cooperative Campaign Analysis Project (CCAP), a national panel study of registered voters, conducted online in six waves, commencing in December of 2007 and concluding in November of 2008 immediately after the presidential election. Throughout, our analysis concentrates on whites, as support for Obama among black Americans was virtually unanimous. ${ }^{1}$

\footnotetext{
${ }^{1}$ In the 2008 ANES, of the 413 blacks who said that they voted for one of the two major candidates in the presidential election, 411 (99.5\%) reported voting for Obama. For details on study design of the 2008 ANES, see http: //www.electionstudies.org. CCAP was a joint venture of research teams from 38 universities. Participating teams of researchers gained access to a set of common questions (Common Content) asked on all waves of all respondents ( $\mathrm{N}$ of approximately 36,000 ), and to specialized questions of their own
}

In the first section of the article, we develop the idea of ethnocentrism, spell out how ethnocentrism should be measured, and build a reliable measure out of materials provided by the 2008 ANES. With an adequate measure in hand, we then ascertain the relationship between ethnocentrism and the 2008 vote. We find, as expected, a strong and robust connection between the two-opposition to Obama among white Americans does indeed derive importantly from ethnocentrism - and we show that multiple efforts to explain away the connection between ethnocentrism and Obama are unavailing. Next, we probe deeper into the meaning of ethnocentrism in 2008, first by grappling with the distinction between ethnocentrism and racism, and then doing the same with the distinction between ethnocentrism and religious intolerance. In the final empirical section, we discuss conditions for the activation of ethnocentrism in 2008, and we demonstrate, as predicted, that ethnocentrism plays a more important role in 2008 than in recent presidential elections, and a more important role in the contest between McCain and Obama than in a hypothetical contest between McCain and Hillary Clinton. In the conclusion of the article, we recapitulate our findings, draw out their implications, and suggest how, despite ethnocentrism's importance in 2008, Obama managed to win.

\section{Ethnocentrism in 2008}

Ethnocentrism divides the world into two opposing camps. From an ethnocentric point of view, groups are either "friend" or they are "foe," eliciting loyalty and favoritism on the one hand or suspicion and disdain on the other. Ethnocentrism is commonly expressed through stereotypes. Stereotypes capture, or rather seem to capture, the characteristics that define a group, that set it apart from others. Most often, such characteristics have to do with underlying dispositions-temperament, intelligence, trustworthiness - the deep core of human nature (Allport [1954] 1989; Fiske 1998).

To measure ethnocentrism expressed in terms of stereotypes, we draw upon a battery of questions originally developed by the National Opinion Research Center at the University of Chicago and included in the 2008 ANES. In these questions, survey respondents are presented with a series of paired antonyms-hard-working versus lazy-and asked to judge whether members of

devising (Team Modules), asked on some waves of some respondents. Interviews were conducted online with registered voters, selected by YouGovPolimetrix's sample matching process (Rivers 2006). 
some designated group — whites—are mostly hardworking, mostly lazy, or somewhere in between. After being asked to judge whites on this score, respondents are asked to make the same judgment, this time about blacks, Asian Americans, and Hispanic Americans, in randomized order. The procedure is then repeated for a second dimension: intelligent versus unintelligent. These questions suit our purposes well. Moral character and intellectual capacity are central features of stereotypes in general (e.g., Fiske 1998; Stangor and Lange 1994), and claims of ingroup superiority are often expressed in just these terms (Brewer and Campbell 1976).

Based on answers to these questions, we created a scale of ethnocentrism, E. We scored $\mathbf{E}$ to range from -1 to +1 . A "perfect" score of +1 means that on both traits, "nearly all" members of the ingroup are believed to be virtuous, and "nearly all" members of all outgroups are believed to be virtue-less. A score of +1 is perfect in the sense that it represents an extreme form of ethnocentrism. A score of -1 is equally perfect, but in the opposite direction: -1 represents a topsy-turvy world in which outgroups are seen as virtuous and ingroups as utterly without virtue. An overall score of 0 , finally, indicates an absence of ethnocentrism; that on average, ingroups and outgroups are indistinguishable. ${ }^{2}$

Figure 1 presents the distribution of $\mathbf{E}$ among white Americans in 2008. As indicated there, ethnocentrism scores follow the familiar bell-shaped curve reasonably well. Figure 1 also reveals that the American public is on balance ethnocentric: first, the curve is displaced away from the neutral point to the right, in the ethnocentric direction; and second, the curve is asymmetric, sloping downward less precipitously to the right, toward the ethnocentric point of view. ${ }^{3}$

Figure 1 reveals what might be called mild ethnocentrism. On the one hand, ingroup favoritism is common. On the other hand, ingroup favoritism is restrained.

${ }^{2}$ The stereotype questions were asked twice, once in the preelection interview (self-administered) and once in the postelection interview (administered by the interviewer). The items are V083207a-V083208d in the preelection and V085174a-V085175d in the postelection. The preelection and postelection scales are equally reliable (preelection, $\alpha=0.77$; postelection, $\alpha=0.81$ ). The correlation between the preelection and postelection measures (uncorrected for measurement error) is 0.52 . The paired t-test comparing preelection $\mathbf{E}$ and postelection $\mathbf{E}$ was not significant ( $\mathrm{p} \sim$ 0.8 ). We averaged responses to the preelection and postelection waves to create our measure of ethnocentrism. For each wave, the formula for building the primary measure of ethnocentrism is:

$$
\begin{aligned}
\mathbf{E}= & \left\{\left(\text { Trait }_{1} \text { ingroup score }- \text { Trait }_{1} \text { average outgroup score }\right)\right. \\
& \left.+\left(\text { Trait }_{2} \text { ingroup score }- \text { Trait }_{2} \text { average outgroup score }\right)\right\} / 2
\end{aligned}
$$

${ }^{3} \mathbf{E}$ is centered at 0.06 , with standard deviation of 0.13 . It ranges from -0.54 to +0.71 .

\section{FIGURE 1 Ethnocentrism among White Americans in 2008 (Based on Group Stereotypes)}

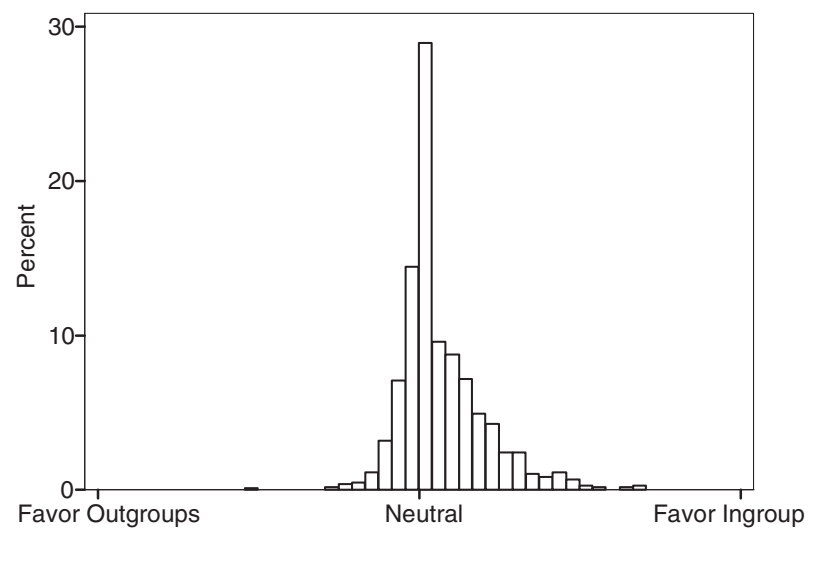

Source: 2008 American National Election Study.

No one is prepared to claim categorical superiority: that members of their group are uniformly intelligent and hardworking, while members of all other groups are uniformly stupid and lazy. What we have here is a sense of gentle superiority, widely shared.

\section{Ethnocentrism and the 2008 Vote}

We know that as a general matter, voters in U.S. presidential elections are motivated by partisanship, policy, and assessment of national conditions. Surely this would be so in 2008. No doubt Obama gained and lost votes because he was a Democrat; gained and lost votes because of the positions he took on major policy matters; gained and lost (mostly gained) votes because of the condition of the country. The multinomial logit results in the first column of Table 1 confirm that these factors all played an important role in the 2008 vote. $^{4}$

${ }^{4}$ Our dependent variable has three categories: abstained $(21.7 \%$ of white respondents), voted for Obama (34.6\%), or voted for McCain (43.7\%). In this analysis, we coded Partisanship (V083097) from -1 (strong Republican) to 1 (strong Democrat). Policy Positions are coded from -1 (conservative) to +1 (liberal). It is a scale based on respondents' answers to four questions of longstanding importance: the trade-off between services and spending, whether government has an obligation to provide a standard of living and jobs to all, defense spending, and government health care. The services and spending question (V083105 and V083108x) and the defense spending question (V083112 and V083115x) were administered with split-sample designs, in which half of the sample received the standard 7-point response scale and the other half of the sample received a series of branching questions. The government 


\section{TABLE 1 Ethnocentrism and Voting against Obama in 2008}

\begin{tabular}{lcc}
\hline Vote Choice & ANES & CCAP \\
\hline Ethnocentrism & $2.52^{* * *}$ & $2.89^{* * *}$ \\
Party Identification & 0.86 & 0.36 \\
& $-3.15^{* * *}$ & $-2.62^{* * *}$ \\
Policy Positions & 0.23 & 0.08 \\
& $-1.42^{* * *}$ & $-2.07^{* * *}$ \\
Assessment of National & 0.32 & 0.09 \\
Economic Conditions & $0.80^{*}$ & $1.55^{* * *}$ \\
Education & 0.44 & 0.17 \\
& -0.19 & $-1.10^{* * *}$ \\
Political Information & 0.96 & 0.18 \\
Female & 0.29 & -0.16 \\
& 0.33 & 0.18 \\
Assessment of Household & $0.41^{*}$ & 0.10 \\
Economic Conditions & 0.23 & 0.10 \\
Intercept & 0.08 & 0.01 \\
& 0.19 & 0.10 \\
lnL & 0.82 & 1.62 \\
p $>$ $\chi^{2}$ & -605.67 & 0.20 \\
N & 0.00 & 0.00 \\
\hline
\end{tabular}

Column 1: Table entry is the MNL coefficient with standard error below.

Column 2: Table entry is the logistic coefficient with standard error below.

${ }^{*} \mathrm{p}<0.1,{ }^{* *} \mathrm{p}<0.05,{ }^{* * *} \mathrm{p}<0.01$.

Full results for the MNL model are available in the online appendix. Source: 2008 American National Election Study (ANES) and Cooperative Campaign Analysis Project (CCAP), as noted.

standard-of-living question (V083128) and the government health care question (V083119) were administered to one-half of the sample. In the issue scale that we create, we take the average of all available responses, provided that the respondent answered at least two of the four questions. "Don't Know" and "Haven't thought about it" responses are set to the midpoint. The additive issue scale has $\alpha=0.62$. When we include the issue items individually, we lose a substantial number of cases, but the direction and statistical significance of the results are unchanged. Assessment of National Economic Conditions is scaled to range from -1 (much worse) to +1 (much better) and is measured through an additive index of how the nation's economy, national unemployment rate, and national inflation rate have done in the past year (V083083x, V083087x, V083089x), with Cronbach's $\alpha=0.56$. Education represents years of schooling, ranging from 0 (0 years) to 1 (17 years). Political Information is an additive scale comprised of three institutional questions asking about which party is more conservative, which party controlled the House, and which party controlled the Senate (V085119/a, V085066, V085067). The scale has $\alpha=0.66$ and ranges from 0 (none correct) to 1 (all correct). Female is a dummy variable based on V081101, coded 1 for females. Assessment of Household Economic Conditions is derived from V083057x, coded from -1
As expected, party identification shaped the vote more than any other single factor: Democrats were very likely to vote for Obama while Republicans were very likely to vote for McCain. Policy positions mattered in a big way as well, with liberals moving to Obama and conservatives moving to McCain. The condition of the economy also contributed: those who believed economic conditions to be worsening were more likely to sign up for change; economic optimists stayed with McCain. All of this is completely familiar and is documented in existing research on the 2008 election (e.g., Lewis-Beck and Nadeau 2009; Pasek et al. 2009).

What is new in Table 1 is that, taking standard explanations into account in 2008, ethnocentrism matters as well. White voters who scored high on the ethnocentrism scale were much more likely to vote against Obama than were white voters who scored low on ethnocentrism. In the 2008 ANES sample of white voters, scores on the ethnocentrism scale range from -0.5 on the low end to +0.7 on the high end. Across this range, the predicted probability of voting against Obama rises sharply, from 0.46 to 0.88 , respectively. ${ }^{5}$

Ethnocentrism did not affect all voters in the same way, though. The effect of ethnocentrism on voting

(much worse) to +1 (much better). Here and throughout, we rely on unweighted regression analysis. Analyses with weights yield substantively similar results.

Full results (predicting abstention) from the MNL model are available in the online appendix. The Hausman test for IIA (estimated via seemingly unrelated regression) provided support for the use of MNL in this case. The coefficients on the full model (with all three options) were not statistically distinguishable from the two versions of the constrained model (omitting one of the three options), at $\mathrm{p}<0.05$. If we set aside those who abstained in 2008 and estimate vote with logit, we obtain substantively and statistically similar results. And, throughout, when we included controls for age and its square, the results for ethnocentrism were unchanged.

${ }^{5}$ The predictions set Female to a value of 1 and all of the other variables to their means. Now, we could have said that as ethnocentrism increased, McCain's prospects soared. We focus on Obama, because we've been assuming that the significant role played by ethnocentrism in the 2008 election has to do with Obama, not McCain. This seems to be so. Respondents to the 2008 ANES were asked to rate Obama and McCain (on the thermometer scale) both before the election and afterwards. To form a dependent variable for this analysis, we averaged the two evaluations (before and after). Obama's mean score on the 0-100-point thermometer rating scale was 56.0; McCain's was 55.3. In a regression analysis, controlling for all of the variables in Table 1, ethnocentrism has a strong and significant effect on ratings of Obama $(b=-27.14$, s.e. $=5.11$, $\mathrm{p}<0.01)$ and no effect at all on ratings of McCain $(b=5.92$, s.e. $=4.45)$. Insofar as ethnocentrism enters into the 2008 vote, it did so by shaping how white Americans think about Barack Obama, not how they think about John McCain. We will have more to say about this, below, when we compare white Americans' responses to hypothetical matchups between McCain and Obama and between McCain and Clinton. 


\section{FIGURE 2 Ethnocentrism and Vote for Obama in 2008 among Democrats, Independents, and Republicans}

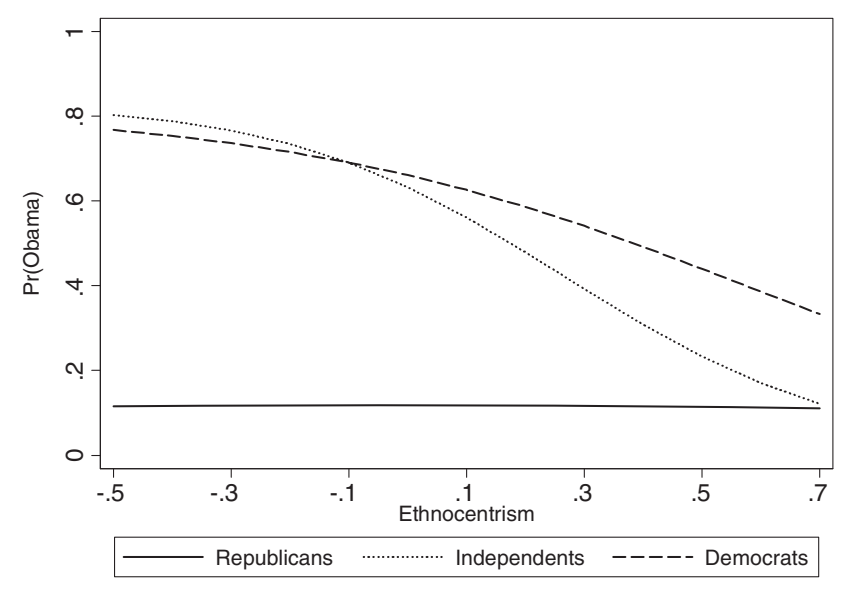

Source: 2008 American National Election Study.

against Obama can be seen more clearly in Figure 2, where we display the predicted vote for Obama as a function of ethnocentrism, when its effect is estimated separately for Democrats, Independents, and Republicans. ${ }^{6}$ As revealed there, the effect of ethnocentrism is most pronounced among Independents; less dramatic but still potent among Democrats; and fades away among Republicans. In 2008, Republicans voted overwhelmingly for Senator McCain regardless of their ethnocentric inclinations. But among Democrats and Independents, as ethnocentrism increased, Obama's prospects plummeted.

The importance of ethnocentrism in the 2008 vote is confirmed in a second and entirely independent test. Here we draw on data from the CCAP, the online panel study of registered voters during the 2008 campaign. Key for our purposes, the September 2008 wave of CCAP included instrumentation that allows us to build a good measure of ethnocentrism. ${ }^{7}$ The CCAP results, shown in column 2 of Table 1, reveal that, just as we saw with NES data,

${ }^{6}$ We reestimate the model in Table 1, separately for Democrats, Independents, and Republicans. MNL estimates for the effect of ethnocentrism were as follows: $\mathrm{b}=2.73$ (s.e. $=1.38, \mathrm{p}<0.05$ ) for Democrats, $\mathrm{b}=4.09$ (s.e. $=1.26, \mathrm{p}<0.01$ ) for Independents, and $\mathrm{b}=-0.20$ (s.e. $=2.14$, ns) for Republicans. The predictions in Figure 2 set Female to a value of 1 and all of the other variables to their means.

${ }^{7} \mathbf{E}$ is based on two trait evaluations (hardworking vs. lazy; intelligent vs. unintelligent) applied to four groups (whites, blacks, Hispanics, and Asians; scap718w/b/a/h, scap719w/b/a/h). For white respondents, $\mathrm{E}$ is centered on 0.04 with standard deviation of 0.14 and Cronbach's $\alpha=0.80$. Partisanship (scap8) is derived from the September wave as well. For Policy Positions, we create a two-item ethnocentrism had a strong, independent, and statistically significant effect on the 2008 vote. ${ }^{8}$

This strong connection between ethnocentrism and opposition to Obama, appearing in two independent tests, also shows up across alternative specifications and alternative measures. These additional tests, all based on the 2008 ANES, appear in Table 2. The first column presents results from a simple replication of the vote model, but with vote replaced by the thermometer score rating of Obama. (We carry out these additional tests with the thermometer rating because it offers a more sensitive measure than vote.) As the first column shows, ethnocentrism has a large negative effect on Obama's rating, as expected.

The second column of Table 2 entertains the possibility that white opposition to Obama in 2008 was rooted, in part, in principle. White Americans might have said no to Obama not so much because they experienced him as different, but because they saw him as advocating a bigger, more intrusive government. Or, they might have voted against him because they saw him as a radical egalitarian bent on spreading the wealth. Obama did in fact advocate an expansion of government programs, and he did in fact push for progressive tax policies. It would not be surprising to discover that, when faced with a choice between Obama and McCain, voters in 2008 were influenced by their views on government and equality. Nor would it be all that surprising to discover that the effect we have so far attributed to ethnocentrism belongs, in part, to principles. ${ }^{9}$

Fortunately, good and reliable measures of Americans' views on government and on equality were included

index based on guaranteed jobs (ocap1104) and health insurance (scap20) $(\alpha=0.73)$. National and Household Economic Assessments are derived from ocap 9 and ocap 1100 , respectively. We also control for Political Information (a 10-item index with $\alpha=0.85$, derived from profile101-110) and Education (profile57), and include a dummy for Female (profile54). All items are coded similarly to how they are in the ANES analysis.

${ }^{8}$ The CCAP sample is drawn from registered voters (as opposed to the ANES sample, which selects eligible voters). Over $96 \%$ of CCAP respondents reported turning out to vote. Hence, with the CCAP data, we use logistic analysis to analyze preference for Obama versus McCain. Multinomial logit (with inclusion of the tiny base category for abstainers) produced nearly identical results. These are unweighted regression analyses. Weighted analyses produced similar results. As with the ANES, the CCAP analyses also suggest that the effect of ethnocentrism is greatest among Independents, sizable among Democrats, and smallest among Republicans.

${ }^{9}$ On the power of principles to shape contemporary public opinion, see Feldman (1988), Kinder and Sanders (1996), and Markus (2001). 
TABLE 2 The Effect of Ethnocentrism on Opposition to Obama Is Robust to Alternative Specifications and Measures

\begin{tabular}{|c|c|c|c|c|c|}
\hline & $\begin{array}{l}\text { Baseline } \\
\text { Model }\end{array}$ & $\begin{array}{l}\text { Adding } \\
\text { Values }\end{array}$ & $\begin{array}{c}\text { Adding } \\
\text { Authoritarianism }\end{array}$ & $\begin{array}{l}\mathrm{E}^{*} \text { based } \\
\text { on Race }\end{array}$ & $\begin{array}{l}\mathrm{E}^{*} \text { based } \\
\text { on Religion }\end{array}$ \\
\hline \multirow[t]{2}{*}{ Ethnocentrism } & $-27.14^{* * *}$ & $-23.73^{* * *}$ & $-23.45^{* * *}$ & $-16.63^{* * *}$ & $-24.17^{* * *}$ \\
\hline & 5.11 & 5.06 & 5.24 & 3.62 & 3.56 \\
\hline \multirow[t]{2}{*}{ Party Identification } & $20.63^{* * *}$ & $18.34^{* * *}$ & $20.06^{* * *}$ & $20.84^{* * *}$ & $19.27^{* * *}$ \\
\hline & 1.13 & 1.15 & 1.14 & 1.09 & 1.27 \\
\hline \multirow[t]{2}{*}{ Policy Positions } & $13.17^{* * *}$ & $7.91^{* * *}$ & $12.76^{* * *}$ & $12.84^{* * *}$ & $12.66^{* * *}$ \\
\hline & 1.81 & 1.90 & 1.81 & 1.78 & 2.13 \\
\hline \multirow{2}{*}{$\begin{array}{l}\text { Assessment of National } \\
\text { Economic Conditions }\end{array}$} & $-8.28^{* * *}$ & $-6.92^{* * *}$ & $-8.63^{* * *}$ & $-8.07^{* * *}$ & $-8.56^{* * *}$ \\
\hline & 2.54 & 2.48 & 2.54 & 2.44 & 2.89 \\
\hline \multirow[t]{2}{*}{ Education } & -0.53 & 0.06 & -4.53 & 0.85 & -5.91 \\
\hline & 5.29 & 5.20 & 5.43 & 5.03 & 6.25 \\
\hline \multirow[t]{2}{*}{ Political Information } & 2.18 & $3.15^{*}$ & 1.51 & 2.04 & 3.19 \\
\hline & 1.91 & 1.89 & 1.92 & 1.89 & 2.23 \\
\hline \multirow[t]{2}{*}{ Female } & 0.20 & -0.27 & -0.22 & 0.56 & 0.46 \\
\hline & 1.33 & 1.29 & 1.33 & 1.30 & 1.53 \\
\hline \multirow{2}{*}{$\begin{array}{l}\text { Assessment of Household } \\
\text { Economic Conditions }\end{array}$} & $4.84^{* *}$ & $5.40^{* *}$ & $4.20^{*}$ & $4.02^{*}$ & $5.63^{* *}$ \\
\hline & 2.24 & 2.18 & 2.24 & 2.19 & 2.60 \\
\hline \multirow[t]{2}{*}{ Egalitarianism } & & $18.76^{* * *}$ & & & \\
\hline & & 4.00 & & & \\
\hline Limited & & $-8.85^{* * *}$ & & & \\
\hline \multirow{3}{*}{$\begin{array}{c}\text { Government } \\
\text { Authoritarianism }\end{array}$} & & 1.96 & & & \\
\hline & & & $-7.59^{* * *}$ & & \\
\hline & & & 2.53 & & \\
\hline \multirow[t]{2}{*}{ Intercept } & 50.94 & 43.27 & 59.01 & 49.64 & 57.57 \\
\hline & 4.60 & 5.05 & 5.30 & 4.42 & 5.59 \\
\hline $\mathrm{p}>\mathrm{F}$ & 0.00 & 0.00 & 0.00 & 0.00 & 0.00 \\
\hline Adjusted $\mathrm{R}^{2}$ & 0.46 & 0.49 & 0.47 & 0.46 & 0.47 \\
\hline $\mathrm{N}$ & 936 & 931 & 935 & 991 & 703 \\
\hline
\end{tabular}

Table entry is the OLS coefficient with standard error below.

Dependent variable is the thermometer score rating, which ranges from 0 (cold) to 100 (warm).

${ }^{*} \mathrm{p}<0.1,{ }^{* *} \mathrm{p}<0.05,{ }^{* * *} \mathrm{p}<0.01$.

Source: 2008 American National Election Study.

in the 2008 ANES. ${ }^{10}$ When we added both to the baseline model, we discovered that there appears to be something to the argument that opposition to Obama was rooted in principle. White Americans who placed a relatively low priority on the place of equality in American society tended to vote against Obama, as did those who were worried over the size and scope of government. But the key point for our purposes is this: taking equality and limited government into account makes virtually no dent

\footnotetext{
${ }^{10}$ Egalitarianism is comprised of an additive index of responses to V085162-V085167 ( $\alpha=0.70)$, coded from 0 (not egalitarian) to 1 (egalitarian). Limited Government is a three-item scale (V085105-V085107) with $\alpha=0.70$, coded from 0 (like more government) to 1 (like limited government).
}

in the estimated effect of ethnocentrism (see column 2 of Table 2).

What about authoritarianism? Authoritarians are distinguished by their predisposition to submit to established authorities and to support violence against targets sanctioned by such authorities (Stenner 2005). As such, authoritarians might have been drawn to McCain and Palin in 2008, who were much clearer in articulating the view that the world remains a very dangerous place. Moreover, authoritarianism and ethnocentrism are correlated: by valuing uniformity and authority over autonomy and diversity, authoritarians come "naturally" to ethnocentrism (Kinder and Kam 2009; Stenner 2005). Perhaps the story we have been telling about ethnocentrism would be better recast as a story about authoritarianism. 
Apparently not. When the standard measure of authoritarianism ${ }^{11}$ is added to our baseline model, the effect due to ethnocentrism barely budges (shown in column 3 of Table 2). Opposition to Obama arises primarily from ethnocentrism, not authoritarianism.

We have argued that the best way to conceive of ethnocentrism is as a form of stereotyping, and the best way to measure ethnocentrism is through stereotypes. Accordingly, our principal measure of ethnocentrism, the one we have relied on so far, is based upon Americans' beliefs about the characteristic attributes of social groups-on their stereotypes. However, given the inevitable fallibility of measurement, it is always prudent to develop additional measures whenever possible. With multiple measures, it is possible to check the robustness of results, to make sure that results are not a product of some undiscovered and unimagined defect of measurement. Hence we created an alternative and second-best measure of ethnocentrism, drawing on the ANES 0-100-point "feeling thermometer" scale. Designed to serve as a general-purpose measure of political evaluation, the thermometer scale asks respondents to rate a series of prominent political and social groups. Counted among these groups in 2008 are whites, blacks, Asian Americans, and Hispanic Americans. The thermometer scale taps emotional aspects of ethnocentrism more directly than does the stereotype battery, but the parallel in measurement between the two is otherwise close. $^{12}$

This second-best measure (call it $\mathbf{E}^{*}$ ) is also scored to range from -1 to +1 . As before, +1 means that the ingroup is rated very warmly and all outgroups are rated very coldly, 0 indicates that on average, ingroup and outgroups elicit indistinguishable feelings, and -1 means that all outgroups are rated very warmly while the ingroup is rated very coldly. ${ }^{13}$ When we substitute $\mathbf{E}^{*}$ for $\mathbf{E}$, we find that while the estimated effect of ethnocentrism is reduced, it remains in absolute and relative terms a strong and significant predictor of opposition to Obama (shown in column 4 of Table 2).

\footnotetext{
${ }^{11}$ Authoritarianism is based on responses to v085158-61. The scale ranges from 0 (not authoritarian) to 1 (authoritarian), with $\alpha=0.59$.

${ }^{12}$ The thermometer score items are V085065c, V085064y, V085064a, and V085064v for evaluations of whites, blacks, Hispanics, and Asians, respectively. $\mathbf{E}^{*}=$ feeling thermometer rating for whites - average feeling thermometer rating for blacks, Hispanics, and Asians.

${ }^{13} \mathbf{E}^{*}$ is highly reliable $(\alpha=0.87)$, with mean of 0.08 and standard deviation of 0.18 . It ranges from -0.80 to 0.83 , covering nearly all of the theoretically possible values. If $\mathbf{E}$ and $\mathbf{E}^{*}$ are alternative (if inevitably imperfect) measures of ethnocentrism, they should be correlated with one another, and they are: Pearson $r=0.45$.
}

In both measures of ethnocentrism we have made use of so far $\left(\mathbf{E}\right.$ and $\left.\mathbf{E}^{*}\right)$, the social groups that are the basis for ethnocentric beliefs and feelings are defined by race (popular understandings of race, that is): white, black, Asian American, and Hispanic American. Of course, this is not the only way to partition the social world, and so not the only way to measure ethnocentrism. Race is a good choice: American politics and society have been organized in important ways around racial conflict from the very outset (e.g., Burnham 1974; Myrdal 1944; Smith 1997), and folk theories of race are widespread and consequential (e.g., Devine 1989; Hirschfeld 1996). But race is not the only choice. Indeed, one of ethnocentrism's distinctive features is its versatility (e.g., Levinson 1949). Depending on circumstances, ingroup and outgroup might be defined by religion, language, sex, occupation, nationality, and more.

With this in mind, we took advantage of new items appearing in the 2008 ANES to fashion a third measure of ethnocentrism, this one based on religious differences. Respondents were asked to rate Christians, Catholics, Jews, Muslims, Hindus, and Atheists on the thermometer scale. Elsewhere in the survey they were asked to report their religious affiliation (if any). We combine the two sets of questions to create a measure of ethnocentrism based on religion, $\mathbf{E}_{\mathrm{R} \cdot}^{*}{ }^{14}$ When we estimate the effect of ethnocentrism on ratings of Obama with ethnocentrism based on religion, we find very much the same result as when ethnocentrism is based on race (see column 5 of Table 2).

In short, the effect of ethnocentrism on opposition to Obama in 2008 seems to be real. The effect is significant and substantial across alternative measures and different specifications. To many white voters, Obama appeared as an outsider, and as such, unworthy of the nation's highest office. $^{15}$

\footnotetext{
${ }^{14}$ Religious identification was coded using V083188x. The measure is unfortunately limited to respondents identifying as Protestants, Catholics, and Jews. The number of Muslims and Hindus was too small in the 2008 ANES to permit even rudimentary analysis, and the survey did not include a category for self-identifying as Atheist. The feeling thermometer variables are V058064c (Catholics); V085064f (Jews); V085065e (Muslims); V085065f (Hindus); V085065g (Christians); and V085065h (Atheists). Ethnocentrism based on religious difference, $\mathbf{E}^{*}{ }_{\mathrm{R}}$, is correlated with $\mathbf{E}^{*}$ (Pearson $r=0.36$ ) and with $\mathbf{E}($ Pearson $r=0.32$ ).

${ }^{15}$ In our conceptualization, ethnocentrism entails ingroup solidarity and outgroup animosity. If this is really so, then the effects of ethnocentrism on opposition to Obama that we have documented so far should reflect both attachment to ingroup and disdain for outgroup. To find out if this is so, we repeated the baseline model, but first we broke the ethnocentrism scale into two separate components, one pertaining to the ingroup and the other pertaining to outgroups. The results offer clear support for our understanding of ethnocentrism. In particular, the results indicate that both
} 


\section{Ethnocentrism, Racism, and Religious Intolerance}

Among the ways that Obama was seen as different, no doubt the most conspicuous was race. When Obama's victory in 2008 was celebrated as historic, it was the election of a black man to the presidency that was taken to be the reason. The morning after the election, the New York Times announced that Obama had succeeded in "sweeping away the last racial barrier in American politics with ease" (Nagourney 2008). To Henry Louis Gates, Jr., Obama's election was "a magical transformative moment ... the symbolic culmination of the black freedom struggle, the grand achievement of a great collective dream (Gates 2009, 2, 3). Obama's rise to prominence and power requires us to consider the relationship between ethnocentrism, on the one hand, and racism, on the other.

Ethnocentrism and racism are related, but they are not the same. Ethnocentrism is broader. Ethnocentrism is a reaction to outsiders in general. The condescension or disdain that the ethnocentric feels applies to strangers of all varieties. Racism, in contrast, is condescension or resentment directed toward a single and particular group. Racism is both an expression of, and a justification for, a set of specific practices of exclusion and oppression directed at African Americans, from slavery on. Ethnocentrism is a universal human appetite; racism is part of American history.

Ethnocentrism and racism are not the same, but they are related. In particular, we argue that they are causally related. Ethnocentrism is a general readiness to partition the world into allies and adversaries, a way of looking at the social world that paves the way to racism. Putting the same point in a different way, the appeal of any particular prejudice will be greater if a person is already ethnocentrically predisposed. Prejudice of any kind, and racism in particular, is all the more comfortable, all the more satisfying, and all the more sensible for someone given to ethnocentrism. Such a person is

... prepared to reject groups with which he has never had contact; his approach to a new and

ingroup pride and outgroup hostility make significant contributions to dislike of Obama. The effect of ingroup pride is negative, sizable, and statistically significant: the more virtuous whites consider their ingroup to be, the cooler they feel toward Obama ( $\mathrm{b}=$ -20.73 , s.e. $=5.52, \mathrm{p}<0.001)$. The effect of outgroup hostility is negative, sizable, and statistically significant as well: the less virtue whites attribute on average to black, Hispanic, and Asian Americans, the cooler they feel toward Obama $(b=-37.16$, s.e. $=6.08$, $\mathrm{p}<0.001)$. strange person or culture is not one of curiosity, interest, and receptivity but rather one of doubt and rejection. The feeling of difference is transformed into a sense of threat and an attitude of hostility. The new group easily becomes an outgroup. (Adorno et al. 1950, 149)

If this is right-if ethnocentrism enables and motivates racism-then certain empirical consequences follow.

First of all, we should find that ethnocentrism and racism are related but distinct, correlated but not identical. To find out if this is so, we made use of a measure of racial resentment included in the 2008 ANES. ${ }^{16}$ Racial resentment presumes the existence of differences between whites and blacks in achievement and status and explains those differences as due to deficiencies in black culture. Racial resentment is especially concerned with black Americans' individualistic shortcomings. From this point of view, blacks fail to display the virtues of hard work and self-sacrifice that white Americans claim as central to the moral ordering of their own lives and to the life of their society. As expected, racial resentment, defined this way, and ethnocentrism $(\mathbf{E})$ are related (Pearson $r=0.30$, $\mathrm{p}<0.01$ ).

A second observable implication of our claim that ethnocentrism is a cause of racism is this: if we add racism to the standard model, the estimated effect due to ethnocentrism on opposition to Obama should diminish. The effect should diminish, but it should not disappear. Obama was an outsider-was seen as an outsider-for reasons in addition to race. And, although Obama's campaign could not avoid race-Obama embodied blackness - it did the next best thing, which was to attempt to neutralize it. By and large, Obama did not talk about race; did not go out of his way to seek the endorsement of prominent black leaders; spent most of his time in front of white audiences; and avoided the rhetoric of racial grievance and compensation. Throughout the campaign, race "was the thing always present, the thing so rarely mentioned" (Remnick 2008, 83; for a good account of the 2008 campaign, see Balz and Johnson 2009). Accordingly, racial resentment should explain some, but not all, of ethnocentrism's effect on Obama's ratings.

The relevant results appear in Table 3. They show, first of all, that racism has a strong independent effect on opposition to Obama, consistent with research on the 2008 election (e.g., Lewis-Beck, Tien, and Nadeau 2010;

\footnotetext{
${ }^{16}$ On the meaning and measurement of racial resentment, see Kinder and Sanders (1996). We use the standard ANES measure of racial resentment (V085143-V085146). The reliability of the additive scale, given by Cronbach's alpha, is 0.77 . The scale ranges from -1 (not resentful) to 1 (resentful).
} 
TABLE 3 Ethnocentrism, Racism, and Religious Intolerance

\begin{tabular}{|c|c|c|c|c|}
\hline ANES & $\begin{array}{c}\text { Baseline } \\
\text { Model }\end{array}$ & $\begin{array}{c}\text { Baseline } \\
\text { Model + } \\
\text { Resentment }\end{array}$ & $\begin{array}{c}\text { Baseline Model + } \\
\text { Anti-Muslim } \\
\text { Sentiment }\end{array}$ & $\begin{array}{c}\text { Baseline } \\
\text { Model + Both } \\
\text { Mediators } \\
\end{array}$ \\
\hline \multirow[t]{2}{*}{ Ethnocentrism } & $-27.36^{\text {*** }}$ & $-14.68^{* * *}$ & $-11.07^{* *}$ & -2.22 \\
\hline & 5.16 & 5.10 & 5.21 & 5.13 \\
\hline \multirow[t]{2}{*}{ Racial Resentment } & & $-14.46^{* * *}$ & & $-12.55^{* * *}$ \\
\hline & & 1.53 & & 1.49 \\
\hline Anti-Muslim & & & $-14.09^{* * *}$ & $-12.24^{* * *}$ \\
\hline Sentiment & & & 1.49 & 1.45 \\
\hline \multicolumn{5}{|l|}{ CCAP } \\
\hline \multirow[t]{2}{*}{ Ethnocentrism } & $1.53^{* * *}$ & $0.68^{* * *}$ & $0.89^{* * *}$ & 0.27 \\
\hline & 0.19 & 0.20 & 0.20 & 0.21 \\
\hline \multirow[t]{2}{*}{ Racial Resentment } & & $0.94^{* * *}$ & & $0.79^{* * *}$ \\
\hline & & 0.06 & & 0.07 \\
\hline Anti-Muslim & & & $0.85^{* * *}$ & $0.72^{* * *}$ \\
\hline Sentiment & & & 0.06 & 0.06 \\
\hline \multicolumn{5}{|c|}{$\begin{array}{l}\text { Top panel: Table entry is the OLS coefficient with standard error below. } \\
\text { Bottom panel: Table entry is the probit coefficient with standard error below. } \\
\text { Models control for partisanship, policy positions, assessment of national economic con- } \\
\text { ditions, education, political information, sex, and assessment of household economic } \\
\text { conditions. } \\
\text { Top panel: Dependent variable ranges from } 0 \text { (cold toward Obama) to } 100 \text { (warm). } \\
\text { Bottom panel: Dependent variable takes values of } 0 \text { (voted for Obama) or } 1 \text { (voted for } \\
\text { McCain). } \\
{ }^{*} p<0.1,{ }^{* *} \mathrm{p}<0.05,{ }^{* *} \mathrm{p}<0.01 \text {. } \\
\text { Source: } 2008 \text { American National Election Study and } 2008 \text { Cooperative Campaign Analysis } \\
\text { Project. }\end{array}$} \\
\hline
\end{tabular}

Pasek et al. 2009; Piston 2010; Tesler and Sears 2010). Table 3 also shows that, with racism held constant, the direct effect of ethnocentrism is cut roughly in half. These findings support our interpretation. Ethnocentrism leads to racism. Racism, in turn, motivates opposition to Obama. Obama triggers ethnocentrism partly, but not entirely, for reasons of race. ${ }^{17}$

Next to race, the most prominent aspect of Obama's otherness had to do with religion. During the 2008 campaign, many Americans came to believe that Obama was Muslim. Never mind that Obama identified as a Christian; that he wrote movingly about his personal search for Christ; that he chose to be baptized in Trinity United Church of Christ in Chicago; that he attended services there regularly; that he was married in Trinity United; and that his two children were baptized there. No matter: in November of 2008, at the close of the presidential campaign, significant proportions of white voters $-27.2 \%$ by one estimate-believed Obama was Muslim. And many more may have had an unconscious or unverbalized belief that Obama was a religious outsider. ${ }^{18}$

\footnotetext{
${ }^{17}$ Sample size is kept consistent across the models in Table 3 to facilitate comparison of results.

${ }^{18}$ This according to the November wave of the 2008-09 American National Election Panel Study. Just $6.8 \%$ of black Americans thought that Obama was Muslim. These figures are similar to those reported by other polls (Fox News, Pew, Princeton Survey Research Associates). When other polls provide an explicit "Don't Know" option, sizable proportions of Americans decline to state Obama's
}

In this context, religious intolerance, more specifically, anti-Muslim sentiment, ought to work the same way in 2008 as racism did. This means, first of all, that ethnocentrism and dislike of Muslims ought to be correlated. Conveniently for our purposes, Muslims were among some 25 groups included as part of the 2008 ANES thermometer scale. White Americans were cool toward Muslims, giving them an average score of 49.9. By comparison, Christians received an average rating of 75.2. Of the full set of 25 groups, Muslims were rated above only three: illegal immigrants, homosexuals, and atheists. As expected, this simple measure of attitude toward Muslims is correlated with ethnocentrism (Pearson $r=0.36$, $\mathrm{p}<0.01){ }^{19}$

If, as we suspect, opposition to Obama rooted in ethnocentrism was a product, in part, of the mistaken but widespread belief that he was or might have been Muslim, then when we add a measure of anti-Muslim sentiment to our standard model, we should see roughly the same thing happen with religious intolerance as we saw with racial intolerance. Table 3 indicates that we do. First of all, dislike of Muslims powerfully predicts opposition to Obama (consistent with results reported by Tesler and Sears 2010). Second, with religious intolerance held constant, the direct effect of ethnocentrism is sharply reduced-in this instance, by more than half. In direct parallel to the case of race, the results on religion are consistent with the conclusion that ethnocentrism leads to anti-Muslim sentiment; that anti-Muslim sentiment generates opposition to Obama; and that Obama triggers ethnocentrism in 2008 partly, but not entirely, for reasons of religion.

What happens when both religious and racial intolerance are taken into account? These results appear in the final column of Table 3. As indicated there, anti-Muslim and antiblack sentiments each contribute significantly and substantially to opposition to Obama. Moreover, with religious intolerance and racial intolerance held constant, the direct effect of ethnocentrism disappears entirely. ${ }^{20}$

religious background, and doubts about Obama's Christianity are likely harbored there. Conscious belief that Obama is a Muslim is not a necessary condition for anti-Muslim sentiment to be activated in evaluations of Obama; priming can be most effective when the perceiver is unaware of what is being primed.

${ }^{19}$ The Muslim thermometer scale rating is V085065e. We coded the variable to range from -1 (very warm) to 1 (very cold). For more on the meaning of anti-Muslim sentiment, see Kalkan, Layman, and Uslaner (2009).

${ }^{20} \mathrm{Put}$ more formally, racial and religious intolerance together $m e$ diate the effect of ethnocentrism on opposition to Obama. We conducted a formal test of mediation using the Sobel test with two mediators (MacKinnon 2008). The Sobel test for each of $j$ mediators 
This extremely tidy pattern of results, based on our analysis of the ANES, is replicated in fine detail when we turn to the CCAP. ${ }^{21}$ The replication results appear in the bottom panel of Table 3. What we found to be true in ANES, we find to be equally true in CCAP.

We conclude that Obama was marked as different in 2008 in two principal ways: by his race and by his (imagined) religion.

\section{Activation of Ethnocentrism}

Ethnocentrism is a deep and abiding habit. But this does not mean that ethnocentrism is an inevitable feature of political life. On the contrary, the part played by ethnocentrism in politics is variable, contingent on circumstance. Candidates, issues, and problems come and go, and they often come and go rapidly. Meanwhile, the carrying capacity of citizens and institutions is distinctly limited. At any single moment, only a few topics can become the center of a society's attention. And only some such topics that manage to command public attention lend themselves to ethnocentric thinking. Ethnocentrism is more likely to be activated insofar as there is close correspondence-a "good fit"-between ethnocentrism, on the one hand, and what is taking place in politics that commands attention, on the other. By correspondence we mean primarily that the events or issues or appeals that happen to occupy center stage in political life lend themselves to an ethnocentric point of view. Fit improves, and activation is more likely, when politics is portrayed as conflict between ingroups and outgroups-between the virtuous and alien.

In previous work, we showed that political events and issues can activate ethnocentrism (Kinder and Kam 2009). Such activation often requires some rhetorical frame to focus the ethnocentric lens on the issue, to direct citizens on how to connect distinctions between the ingroup and outgroup with a policy opinion. The ethnocentric lens focuses easily and readily upon differences that can be

is conducted using the following formula: $t_{j}=a_{j}{ }^{*} b_{j} /\left(b_{j}{ }^{2 *} s_{\mathrm{aj}}{ }^{2}+\right.$ $\left.a_{j}{ }^{2 *} s_{\mathrm{bj}}{ }^{2}\right)^{0.5}$, where $\mathrm{a}_{j}$ represents the OLS regression coefficient for $\mathrm{E}$ on each mediator $j, \mathrm{~b}_{j}$ represents the OLS regression coefficient for each mediator $j$ on evaluations of Obama, and $s$ are the respective standard errors. Using the values from the regressions estimated in the ANES 2008, $t_{\text {resentment }}=-5.86$, which yields $\mathrm{p}<0.0001$, suggesting statistically significant mediation. Similarly, calculating $t_{\text {anti-Muslims }}=-6.56$, which yields $\mathrm{p}<0.0001$, also suggesting statistically significant mediation. The same results appear for CCAP.

${ }^{21}$ We measure Racial Resentment with scap70-73, $\alpha=0.86$. We measure anti-Muslim sentiment with response to a 5-point question about favorability toward Muslims (ocap300mus). simply and clearly observed and comprehended, and, we argue, candidate characteristics-particularly those that are easily observable or comprehensible-fit particularly well into this criteria.

With ethnocentrism in mind, then, the 2008 election was unusual. In 2008, one of the major party candidates was marked by difference. Obama was black, and he was, to a surprising number of Americans, Muslim. Indeed, he was the embodiment of otherness. If this is right, and if we are right to claim that the potency of ethnocentrism depends on circumstance, then ethnocentrism should not simply matter in 2008, it should matter more in 2008.

More compared to what? It is at this point that we exploit the great advantage of the American National Election Studies: the provision of continuity and comparability in the study of American national elections. In every presidential year since 1952, ANES respondents are interviewed before the election and once again afterward, questioned each time in person by a professional interviewer. Each year, adults of voting age are selected into ANES studies through comparable probability sampling designs. And of crucial importance for our project, the standard ethnocentrism scale, E, was included not only in the 2008 American National Election Study, but also in the four preceding presidential ANES studies as well. This permits us to compare the effect of ethnocentrism in 2008 to the effect of ethnocentrism under more orthodox conditions.

Table 4 reports the results of comparable vote models estimated separately for each of the five most recent American presidential elections: Bill Clinton's victory over George H. W. Bush in 1992; Clinton's defeat of Robert Dole in 1996; George W. Bush's paper-thin victory over Al Gore in 2000; Bush's defeat of John Kerry in 2004; and Barack Obama's victory over John McCain in 2008. Every election is, of course, unusual in some degree. But with respect to the activation of ethnocentrism, we say that 2008 stands alone, and that for the purposes of an empirical test, the four presidential elections that immediately precede 2008 provide an adequate comparison set. $^{22}$

\footnotetext{
${ }^{22}$ All variables are constructed and coded to be as similar as possible to the 2008 analyses. For example, for Policy Positions, the same four issues (spending and services, defense, health insurance, and guaranteed jobs) are used across all years. In 2000, we use only those respondents who were administered the 7-point issue questions, to preserve comparability across elections. The measure of ethnocentrism is based upon the stereotype battery, with some variation in the fine details. In 2004 and 2000, E is based upon stereotypes of four groups (whites, blacks, Asians, and Hispanics) evaluated along three traits (hardworking/lazy; intelligent/unintelligent; not trustworthy/trustworthy). In 1996, E is based upon the same three traits, but only three groups are
} 
TABLE 4 The Activation of Ethnocentrism in 2008

\begin{tabular}{|c|c|c|c|c|c|}
\hline $\begin{array}{l}\text { Vote Choice } \\
\text { (GOP vs. DEM) }\end{array}$ & $\begin{array}{c}2008 \\
\text { McCain/Obama }\end{array}$ & $\begin{array}{c}2004 \\
\text { Bush/Kerry }\end{array}$ & $\begin{array}{c}2000 \\
\text { Bush/Gore }\end{array}$ & $\begin{array}{c}1996 \\
\text { Dole/Clinton }\end{array}$ & $\begin{array}{c}1992 \\
\text { Bush Sr./Clinton }\end{array}$ \\
\hline \multirow[t]{2}{*}{ Ethnocentrism } & $2.52^{* * *}$ & 0.27 & 0.68 & -0.52 & $1.56^{* *}$ \\
\hline & 0.86 & 1.03 & 0.99 & 0.70 & 0.67 \\
\hline \multirow[t]{2}{*}{ Partisanship } & $-3.15^{* * *}$ & $-3.23^{* * *}$ & $-3.22^{* * *}$ & $-2.86^{* * *}$ & $-2.94^{* * *}$ \\
\hline & 0.23 & 0.28 & 0.29 & 0.21 & 0.20 \\
\hline \multirow[t]{2}{*}{ Policy Positions } & $-1.42^{* * *}$ & $-1.91^{* * *}$ & $-1.46^{* * *}$ & $-2.35^{* * *}$ & $-1.64^{* * *}$ \\
\hline & 0.32 & 0.48 & 0.49 & 0.42 & 0.37 \\
\hline \multirow{2}{*}{$\begin{array}{l}\text { Assessment of National } \\
\text { Economic Conditions }\end{array}$} & $0.80^{*}$ & $1.22^{* * *}$ & $-0.54^{*}$ & $-2.03^{* * *}$ & $1.44^{* * *}$ \\
\hline & 0.44 & 0.32 & 0.31 & 0.40 & 0.34 \\
\hline \multirow[t]{2}{*}{ Education } & -0.19 & -0.62 & $-2.45^{* *}$ & 1.33 & -0.40 \\
\hline & 0.96 & 1.18 & 1.19 & 0.89 & 0.85 \\
\hline \multirow[t]{2}{*}{ Awareness } & 0.29 & $-1.17^{*}$ & -0.65 & $-1.07^{* *}$ & -0.70 \\
\hline & 0.33 & 0.60 & 0.55 & 0.53 & 0.46 \\
\hline \multirow[t]{2}{*}{ Female } & $0.41^{*}$ & 0.26 & -0.31 & -0.33 & 0.33 \\
\hline & 0.23 & 0.30 & 0.29 & 0.23 & 0.22 \\
\hline Assessment of Household & -0.08 & $0.48^{*}$ & 0.20 & $-0.41^{*}$ & 0.21 \\
\hline Economic Conditions & 0.19 & 0.27 & 0.32 & 0.23 & 0.22 \\
\hline \multirow[t]{2}{*}{ Intercept } & 0.26 & 1.38 & 2.59 & -0.33 & 0.86 \\
\hline & 0.82 & 0.97 & 1.02 & 0.78 & 0.72 \\
\hline $\ln L$ & -605.67 & -389.05 & -380.60 & -604.44 & -726.33 \\
\hline $\mathrm{p}>\chi^{2}$ & 0.00 & 0.00 & 0.00 & 0.00 & 0.00 \\
\hline $\mathrm{N}$ & 909 & 654 & 560 & 943 & 1093 \\
\hline
\end{tabular}

Table entry is the MNL coefficient with standard error below.

${ }^{*} \mathrm{p}<0.1,{ }^{* *} \mathrm{p}<0.05,{ }^{* * *} \mathrm{p}<0.01$.

Full results are available in the online appendix.

Source: 1992-2008 American National Election Studies.

Table 4 shows that, as expected, ethnocentrism played an important part in the 2008 election-but not elsewhere. The effect of ethnocentrism on the vote is effectively zero in 1996, 2000, and 2004. Against expectations, the effect of ethnocentrism is statistically significant in 1992, though, consistent with expectations, smaller than the effect in 2008. Altogether, these results support the general proposition that the activation of ethnocentrism depends on the political circumstances of the times. ${ }^{23}$

evaluated (evaluations of Asians were not included in the survey). In 1992, $\mathbf{E}$ is based upon stereotypes of all four groups, evaluated along three traits (hardworking/lazy; intelligent/unintelligent; violent/peaceful). Full results (predicting abstention) from the MNL models are available in the online appendix.

${ }^{23}$ Is the effect of ethnocentrism in 2008 statistically distinguishable from its effects in previous years? In every case but one, yes. The difference in the effect of ethnocentrism on the vote in 2008 versus 2004 (one-tailed $\mathrm{p}<0.08$ ); versus 2000 (one-tailed $\mathrm{p}<0.09$ ); versus 1996 (one-tailed $\mathrm{p}<0.01$ ); and versus 1992 ( $\mathrm{p} \sim 0.41$ ). In magnitude, the effect of a change in $\mathrm{E}$ from -0.5 to +0.7 corresponds with substantial declines in predicted support for the Democratic candidate. In 2008, the predicted support shifts from 0.54 to 0.12 .
A second and distinct test of activation takes advantage of the 2008 Democratic nomination contest. Recall that Senator Clinton entered the season as the presumptive nominee. She enjoyed the backing of her party, an experienced and professional staff, endorsements from prominent African Americans, money to burn, and widespread public support. In a tight and fiercely contested race, it was Obama who eventually emerged victorious, of course, but in the early spring of 2008 the outcome was far from clear.

Hence it made perfect sense for respondents in the March wave of the CCAP to be asked about two hypothetical races: one between McCain and Obama (should Obama turn out to be the Democratic nominee) and the other between McCain and Clinton (should Clinton prove victorious). In March, both contests were hypothetical but both were realistic. Comparing the importance of ethnocentrism across the two allows us to test activation while holding important factors constant: the state

In 2004, 2000, and 1996, the effects are quite small. In 1992, the effect is sizable but smaller (from 0.58 to 0.24 ). 


\section{TABLE 5 The Activation of Ethnocentrism by Obama, not Clinton}

\begin{tabular}{lcc}
\hline & $\begin{array}{c}\text { Prefer McCain } \\
\text { over Obama }\end{array}$ & $\begin{array}{c}\text { Prefer McCain } \\
\text { over Clinton }\end{array}$ \\
\hline Ethnocentrism & $1.68^{* * *}$ & -0.01 \\
Partisanship & 0.19 & 0.19 \\
& $-1.14^{* * *}$ & $-1.46^{* * *}$ \\
Policy Positions & 0.04 & 0.04 \\
& $-0.87^{* * *}$ & $-0.82^{* * *}$ \\
Assessment of National & 0.05 & 0.05 \\
Economic Conditions & $0.57^{* * *}$ & $0.41^{* * *}$ \\
Education & 0.09 & 0.09 \\
Awareness & $-0.41^{* * *}$ & $-0.24^{* *}$ \\
& 0.09 & 0.09 \\
Female & $-0.36^{* * *}$ & 0.06 \\
& 0.09 & 0.10 \\
Assessment of Household & 0.03 & $-0.19^{* * *}$ \\
Economic Conditions & 0.05 & 0.05 \\
Intercept & $0.11^{* *}$ & 0.07 \\
lnl & 0.05 & 0.06 \\
N ${ }^{2}$ & 0.98 & 0.78 \\
\hline
\end{tabular}

Table entry is the probit coefficient with standard error below. Dependent variable is coded as 0 (prefer Democratic candidate) and 1 (prefer McCain).

${ }^{*} \mathrm{p}<0.1,{ }^{* *} \mathrm{p}<0.05,{ }^{* * *} \mathrm{p}<0.01$.

Source: 2008 Cooperative Campaign Analysis Project.

of the economy, the ongoing war, and the identity of the Republican opponent.

Perhaps this is a hard test for us, since, after all, Senator Clinton-Hillary Clinton-embodied another dimension of otherness through her sex. Perhaps ethnocentrism ought to be directed toward her as well as Obama. However, in prior work (Kinder and Kam 2009), we found that ethnocentrism is not activated in the domain of gender, possibly because women as a broad social grouping are less susceptible to demonization than other social categories such as race, religion, and sexual preference. Hence, we suspect that the ethnocentrism effect will be directed toward Obama, not Clinton.

And this is what we find. Table 5 provides estimates of the effect of ethnocentrism in each of two hypothetical matchups. In column 1, we see the familiar result: in the contest between McCain and Obama, ethnocentrism stands out as very important. In column 2, the familiar result disappears: in the contest between McCain and Clinton, ethnocentrism has no effect at all.

\section{FIGURE 3 Ethnocentrism and Support for the Democratic Candidate in Two Hypothetical Matchups}

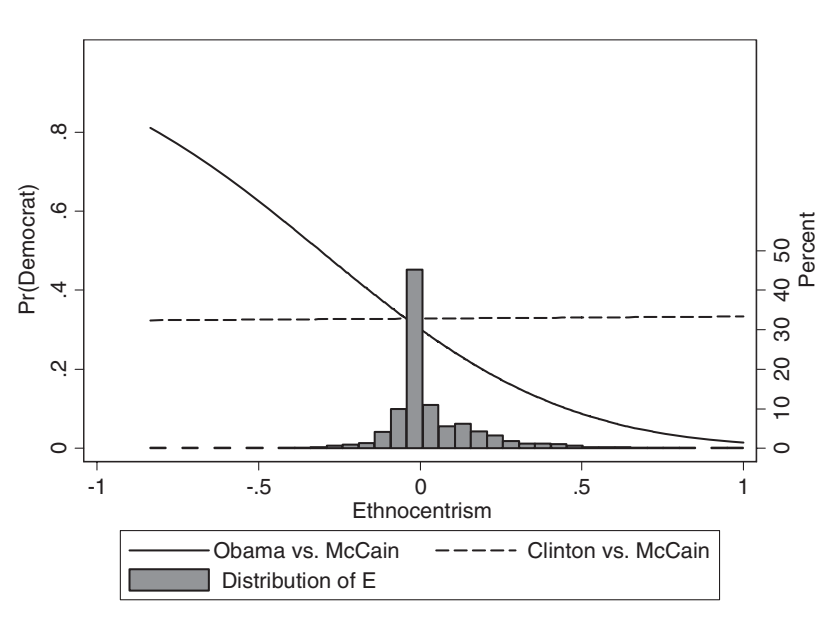

Source: 2008 Cooperative Campaign Analysis Project.

That said, was Obama helped or hurt by ethnocentrism? This question may seem odd. Up to this point, we have concentrated on ethnocentrism as a force working against Obama. Yet, it is entirely possible that voters who reject ethnocentrism might have been especially attracted to Obama. Figure 3 shows that Obama does indeed pick up support (relative to what Clinton would have received) among the small proportion of white voters who score below -0.05 on the ethnocentrism scale and loses support (relative to what Clinton would have received) among those who score -0.05 or above on the ethnocentrism scale (roughly $82 \%$ of the sample). ${ }^{24}$ On balance, ethnocentrism hurts rather than helps Obama, since the former are vastly outnumbered by the latter.

In short, the part played by ethnocentrism in American politics can be large or small, depending on conditions. Candidate characteristics, we say, can be a particularly clear and powerful means of triggering ethnocentrism. By virtue of Obama's otherness-his race and his imagined religion-the conditions were right in 2008. Ethnocentrism was activated. Obama paid a price.

\section{Conclusion}

Ethnocentrism is a deep-seated habit of thinking that partitions the world into ingroups and outgroups-into "us" and "them." Defined this way, ethnocentrism is pervasive

\footnotetext{
${ }^{24}$ In the predicted probability computations, we set Female to 1 and
} other values to their sample means. 
in the United States and around the world. Previous research has established that Americans differ from one another in their level of ethnocentrism and that this difference has important consequences for the positions they take on a wide range of government policies (Kinder and Kam 2009). Here we investigated whether ethnocentrism might also have an important part to play in American presidential elections, selecting the 2008 contest, and the candidacy of Barack Obama, as a likely case in point.

As we suspected it would, ethnocentrism emerged from our analysis as a potent short-term force in 2008 . Faced with a choice between John McCain and Barack Obama, voters were swayed by the usual and familiar play of factors-party identification, views on policy, the state of the economy - but also by one unusual and unfamiliar factor: ethnocentrism. The effect of ethnocentrism on the white vote was significant, substantial, and robust. Many voters looked at Barack Obama in 2008 and saw an outsider, a black man committed to a strange religion.

Ethnocentrism is a deep-seated habit, but the part it plays in politics is contingent on circumstance. By virtue of his race and religious convictions, Obama turned the 2008 American presidential election into an exceptional case, one that activated ethnocentric sentiments powerfully.

We do not mean to suggest that only candidate characteristics can trigger ethnocentrism. Indeed, in prior work (Kinder and Kam 2009) we showed that political events and policy framing can activate ethnocentrism across a range of policy domains. Candidates, parties, and interest groups have various ways to signal alignment with and opposition to various social groups: by proposing particular policies that visibly favor some groups at the expense of others; by emphasizing or neglecting problems that are of special concern to a particular group; by keeping certain company, spending time in the public eye with iconic representatives of one group or another; and more.

We may have stumbled upon one such case ourselves. Contrary to expectation, we found an effect of ethnocentrism in the 1992 presidential election, albeit a modest one. Perhaps this finding is a reflection of the unusually strident Republican National Convention of that year, which featured a declaration of a "culture war" against homosexuals, abortionists, and immigrants. While we think the most effective signal of all is membership itself (perceived membership, we should say), as in Barack Obama's racial background and religious faith, we should be mindful that there are other ways to activate ethnocentrism.

Given all the evidence we have marshaled here, the reader might well be thinking: but Obama won. How could this be, if ethnocentrism intruded so visibly and consequentially in 2008? Good question.

Obama lost votes among whites due to his race and his imagined religion, but other factors present in 2008 worked in his favor. ${ }^{25}$ For one thing, black turnout increased sharply in 2008. From 1980 through 2004, blacks made up $11 \%$ of the electorate. In 2008, this percentage jumped to $13 \%$. Because African Americans voted nearly unanimously for Obama in 2008, the successful mobilization of the black vote by the Obama campaign yielded a rich harvest of votes, an increase in the popular vote of about $2 \%$.

More important still, national conditions favored the Democrats overwhelmingly. Presidential elections are, in very important part, a judgment of the incumbent party's performance in two domains: economic prosperity and peace and security (e.g., Hibbs 2000; Rosenstone 1983). With this in mind, consider John McCain's predicament in 2008. He found himself with two Herculean tasks: to defend an increasingly unpopular war and to persuade the country that it should trust the Republican Party to fix the economic mess that it had apparently just created.

"Mess" understates things considerably. By the summer of 2008, energy prices were soaring, housing prices were falling, and credit was drying up. Freddie Mac and Fannie Mae, the two mortgage titans that together owned or guaranteed roughly half the home loans of Americans, teetered on the edge of collapse. Early in September, Lehman Brothers went belly-up. Merrill Lynch was bought by Bank of America, narrowly escaping a similar fate. American International Group (AIG), the gigantic insurance firm, was rescued by an 85 billion dollar government loan. Industrial production fell, unemployment rose, and the stock market tumbled. The credit crisis was spreading into the real economy and rippling through Europe and Asia. As the election approached, American confidence in the economy plunged to a record low.

This cascade of terrible news played directly into Obama's hands. Plausible models of presidential elections, ones that take into account in reasonable ways economic conditions and peace and security, predicted a landslide for the Democrats in 2008. Obama in fact won $53.7 \%$ of the vote; the models say Obama "should" have won close to $60 \%$ of the vote. The models imply that if the timing had gone a little differently, if the surge in Iraq had begun a bit earlier and especially if the great recession and the collapse of major financial institutions had not begun until after the first week in November, Obama would not have been elected at all.

${ }^{25}$ This interpretation of the 2008 election is taken from Kinder and Dale-Riddle (2011). 
As things turned out, of course, Obama was elected. Our point here is that he was elected despite ethnocentrism. Race and religion entered into the 2008 election in a significant way. Only the dismal and frightening conditions that surrounded the election, which were widely blamed on Republicans, kept the election in the Democratic column.

The 2008 election provided unusually fertile grounds for the activation of ethnocentrism. On the idea that we would rather see election outcomes decided by ideas and results and character than by intolerance, prejudice, and ethnocentrism, we might take some consolation over 2008's seeming exceptionalism. Perhaps, but there is another way to look at it. The 2008 election was unusual, one might say, because the stable two-party system that has characterized American politics for so long generally protects against the selection of outsiders as presidential candidates. Candidates like Obama are rarely nominated. Over the sweep of American history, only one black person has run for president at the head of a major party; no women; only three Catholics; no Muslims (despite what a significant fraction of the American public continues to believe); no Jews; no Atheists; no Latinos; no Asian Americans; no (uncloseted) gays. Looking over the full set of presidential candidates reminds us that in some important respects, the United States remains an exclusive political community - a reflection, we would suggest, of the power and persistence of ethnocentrism.

\section{References}

Adorno, T. W., Else Frenkel-Brunswik, Daniel J. Levinson, and R. Nevitt Sanford. 1950. The Authoritarian Personality. New York: Harper and Row.

Allport, Gordon W. 1954. The Nature of Prejudice. Cambridge, MA: Addison-Wesley.

Balz, Dan, and Haynes Johnson. 2009. The Battle for America 2008: The Story of an Extraordinary Election. New York: Viking.

Brewer, Marilynn B., and Donald T. Campbell. 1976. Ethnocentrism and Intergroup Attitudes. New York: John Wiley.

Burnham, Walter Dean. 1974. "The United States: The Politics of Heterogeneity.” In Electoral Behavior, ed. Richard Rose. New York: Free Press, 653-725.

Devine, Patricia G. 1989. "Stereotypes and Prejudice: Their Automatic and Controlled Components." Journal of Personality and Social Psychology 56(1): 5-18.

Feldman, Stanley. 1988. "Structure and Consistency in Public Opinion: The Role of Core Beliefs and Values." American Journal of Political Science 32(2): 416-40.

Fiske, Susan T. 1998. "Stereotyping, Prejudice, and Discrimination." In Handbook of Social Psychology, 4th ed., ed.
Daniel Gilbert, Susan T. Fiske, and Lindzey Gardner. Boston: McGraw Hill, 357-411.

Gates, Henry Louis, Jr. 2009. “Introduction.” In Barack Obama: A Pocket Biography of Our 44th President, ed. Steven J. Niven. New York: Oxford University Press, 1-4.

Hibbs, Douglas A., Jr. 2000. "Bread and Peace: Voting in U.S. Presidential Elections.” Public Choice 104(1-2): 14980.

Higham, John. [1983] 1955. Strangers in the Land: Patterns of American Nativism, 1860-1925. New Brunswick, NJ: Rutgers University Press.

Hirschfeld, Lawrence A. 1996. Race in the Making. Cambridge, MA: MIT Press.

Kalkan, Kerem Ozan, Geoffrey C. Layman, and Eric M. Uslaner. 2009. "'Bands of Others?' Attitudes toward Muslims in Contemporary American Society." American Journal of Political Science 71(3): 847-62.

Kinder, Donald R., and Allison Dale-Riddle. 2011. The End of Race? 2008, Obama, and Racial Politics in America. New Haven, CT: Yale University Press.

Kinder, Donald R., and Cindy D. Kam. 2009. Us against Them: Ethnocentric Foundations of American Public Opinion. Chicago: University of Chicago Press.

Kinder, Donald R., and Lynn M. Sanders. 1996. Divided by Color. Chicago: University of Chicago Press.

LeVine, Robert A. 2001. "Ethnocentrism." International Encyclopedia of the Social and Behavioral Sciences: 4852-54.

Levinson, Daniel J. 1949. "An Approach to the Theory and Measurement of Ethnocentric Ideology." Journal of Psychology 28(1): 19-39.

Lewis-Beck, Michael S., and Richard Nadeau. 2009. "Obama and the Economy in 2008." PS: Political Science \& Politics 42(3): 479-83.

Lewis-Beck, Michael S., Charles Tien, and Richard Nadeau. 2010. “Obama's Missed Landslide: A Racial Cost?" PS: Political Science \& Politics 43(1): 69-76.

MacKinnon, David P. 2008. Introduction to Statistical Mediation Analysis. New York: Lawrence Erlbaum.

Markus, Gregory B. 2001. "American Individualism Reconsidered." In Citizens and Politics: Perspectives from Political Psychology, ed. James H. Kuklinski. New York: Cambridge University Press, 401-32.

Myrdal, Gunnar. 1944. An American Dilemma: The Negro Problem and Modern Democracy. New York: Harper and Row.

Nagourney, Adam. 2008. "Obama Elected President as Racial Barrier Falls." New York Times, November 5, section A.

Pasek, Josh, Alexander Tahk, Yphtach Lelkes, Jon. A. Krosnick, B. Keith Payne, Omair Akhtar, and Trevor Tompson. 2009. "Determinants of Turnout and Vote Choice in the 2008 U.S. Presidential Election: Illuminating the Impact of Racial Prejudice and Other Considerations." Public Opinion Quarterly 73(5): 943-94.

Piston, Spencer. 2010. "How Explicit Racial Prejudice Hurt Obama in the 2008 Election." Political Behavior 32(4): 431-51.

Remnick, David. 2008. "The Joshua Generation." The New Yorker, November 17, 68-83. 
Rivers, Douglas R. 2006. "Sample Matching: Representative Sampling from Internet Panels." Polimetrix White Paper Series.

Rosenstone, Steven J. 1983. Forecasting Presidential Elections. New Haven, CT: Yale University Press.

Smith, Rogers M. 1997. Civic Ideas. New Haven, CT: Yale University Press.

Stangor, Charles, and James E. Lange. 1994. "Mental Representations on Social Groups: Advances in Understanding Stereotypes and Stereotyping." Advances in Experimental Social Psychology 26: 357-416.

Stenner, Karen. 2005. The Authoritarian Dynamic. Cambridge: Cambridge University Press.

Sumner, William Graham. [1906] 2002. Folkways: A Study of Mores, Manners, Customs, and Morals. Mineola, NY: Dover.

Tesler, Michael, and David O. Sears. 2010. Obama's Race. Chicago: University of Chicago Press.

\section{Supporting Information}

Additional Supporting Information may be found in the online version of this article:

Complete results for Table 1: Ethnocentrism and Voting against Obama in 2008

Complete results for Table 4: The Activation of Ethnocentrism in 2008

Please note: Wiley-Blackwell is not responsible for the content or functionality of any supporting materials supplied by the authors. Any queries (other than missing material) should be directed to the corresponding author for the article. 